\title{
Cajuput Oil
}

National Cancer Institute

\section{Source}

National Cancer Institute. Cajuput Oil. NCI Thesaurus. Code C74291.

The essential oil from the leaves of Melaleuca leucadendra. Cajaput oil is used as an expectorant, for treatment of tooth and gum pain, and for its antiseptic properties. 